\title{
Effect of Moisture and Machine Parameters on De-husking Efficiency of Kodo Millet
}

\author{
Parv Nayak $^{1^{*}}$, A.K. Gupta ${ }^{2}$, Preeti Jain ${ }^{2}$ and Sheela Pandey ${ }^{2}$ \\ ${ }^{1}$ Department of Agricultural Processing and Food Engineering, CAET, \\ Odisha University of Agriculture and Technology, Bhubaneswar, 751003, Odisha, India \\ ${ }^{2}$ Department of Post-Harvest Process and Food Engineering, \\ College of Agricultural Engineering, JNKVV, Jabalpur, 482004, (M .P), India
}

*Corresponding author

\section{Keywords}

Millet, Kodo, Dehusker, Efficiency.

Article Info

Accepted:

15 January 2019

Available Online:

10 February 2019

\section{A B S T R A C T}

Studies on engineering properties of variety JK 41 Kodo (Paspalum scrobiculatum L.) was conduct at 12 and $14 \%$ moisture content wet basis (w.b). The average length, width, thickness, size and sphericity of Kodo millet at $12 \%$ moisture content (w.b) were $2.69 \mathrm{~mm}$, $2.02 \mathrm{~mm}, 1.31 \mathrm{~mm}, 1.92 \mathrm{~mm}$ and $71.68 \%$ respectively. However, the average values of length, width, thickness, size and sphericity of Kodo millet at $14 \%$ moisture content (w.b) were $2.80 \mathrm{~mm}, 2.39 \mathrm{~mm}, 1.39 \mathrm{~mm}, 2.09 \mathrm{~mm}$, and $74.76 \%$ respectively. It was observed that the bulk density of Kodo millet decreased with increase in moisture content. The average value of bulk density of Kodo millet at $12 \%$ and $14 \%$ moisture content were 957.23 and $954.81 \mathrm{~kg} / \mathrm{m}^{3}$, respectively (Balasubramanian and Vishwanathan, 2010) also observed that the bulk density of millets decreased linearly with increment the moisture content. The average value of angle of repose for the Kodo millet increased from $26.23^{\circ}$ to $26.50^{\circ}$ with increment in moisture content (w.b.) from $12 \%$ and $14 \%$ (Sirsat and Patel, 2008; Balasubramanian and Vishwanathan, 2010) also observed the increment in angle of repose of Kodo millet with increment in moisture content. The Kodo millet de-husker composed of three basic units i.e. feeding unit, de-husking unit and discharge unit. The maximum de-husking efficiency of $75.29 \%$ and $72.51 \%$ for pretreated Kodo millet at $14 \%$ moisture content (w.b.) with $1.5 \mathrm{~mm}$ and $2.00 \mathrm{~mm}$ clearance between the abrasive surfaces, was obtained at $380 \mathrm{rpm}$ respectively at the feed rate of $12 \mathrm{~kg} / \mathrm{hr}$. Cost of dehusking per kilogram of Kodo millet was Rs. 5.60.

\section{Introduction}

Kodo millet (Paspalum scrobiculatum L.) is nutritionally superior and good source of protein, carbohydrate, minerals, fibers, vitamins and micronutrients which make it suitable for industrial scale utilization in food stuff. The husk on the minor millet is tightly attached with the endosperm thereby making its removal difficult during de-husking operation. Traditionally the minor millets are de-husked manually with help of wooden mortar and pestle and grinding stone. The milling of Kodo millet is still being performed 
by hand/foot pounding. The processing is labour intensive and time consuming process. An effort has been made to mechanize the dehulling of Kodo millets to reduce the drudgery of processing operation. $100 \mathrm{~kg} / \mathrm{hr}$ de-husking capacity millet de-husker has been designed by Central Institute of Agricultural Engineering (CIAE), Bhopal (Anon, 2013). The de-hulling efficiency of the machine is about 95 per cent. A multigrain centrifugal de-huller with $100 \mathrm{~kg} / \mathrm{hr}$ capacity was developed by TNAU. The machine de-hulling efficiency is 95 percent. Vivek thresher-cumpearler was designed and developed by PHET, VAPKAS, Almora centre with capacity of $60 \mathrm{~kg} / \mathrm{hr}$ (Dixit et al., 2011). Mid capacity, non-portability and high capital investment are some of the impediments in popularization of existing Kodo millet dehusker. The study was planned to develop a small capacity Kodo millet de-husker suitable for farm processing of Kodo millets, performance evaluation of developed Kodo millet de-husk and to determine the cost of de-hulling operation.

\section{Materials and Methods}

\section{Description of Kodo millet de-husker}

The Kodo millet de-husker has three basic units i.e. feeding unit, de-husking unit and discharge unit. It consists of a steady metallic frame, feed hopper, de-husking unit (dehusking roller and outer hollow punched cylinder), adjustment screw for clearance adjustment, bearings, pulley, belt, starter cum controller and electric motor. The machine occupied a floor area of $0.7 \mathrm{~m} \times 0.4 \mathrm{~m}$ and its height is $1.1 \mathrm{~m}$. Kodo millet de-husker is shown in Figure 1 and 2.

\section{Mechanism of operation of de-husker}

Kodo millet de-husker, was designed which utilizes the abrasion and frictional forces generated by the rotation of the abrasive surface of the de-husking roller unit along with the inter-granular frictional forces generated due to movement of the grains shown in figure 3 . The required abrasion forces in de-husker will be generated by rotating an inner abrasive roller fitted inside a concentric fixed abrasive outer cylinder.

The present investigation was undertaken to study some of the physical/engineering properties and to evaluate the performance of Kodo millet de-husker. To evaluate the performance of the developed Kodo millet dehusker, raw Kodo millets of variety JK 41, were procured from local market. Kodo millets were cleaned before the performance evaluation. Moisture content of procured Kodo millet was $11.2 \%$ (w.b). The sorted samples were then soaked in water at $30^{\circ} \mathrm{C}$ for 2 hour and were drained and dried in shade for 5 hour in ambient condition. It was reported that $12 \%$ (w.b) to $14 \%$ (w.b) were optimum moisture content for milling of Grains and millets (Azalinia et al., 2002). Samples of $12 \%$ (w.b) and $14 \%$ (w.b) moisture content were prepared by the addition of calculated amount of water through mist spray. From the experimental point of view, $9 \mathrm{ml}$ and $31.25 \mathrm{ml}$ of water were required to convert $1 \mathrm{~kg}$ of Kodo millet at $11.2 \%$ (w.b) to make the samples at $12 \%$ (w.b) and $14 \%$ (w.b), respectively

Different properties of Kodo millet such as moisture content, size, angle of repose, bulk density, were determined using standard techniques.

\section{Moisture content}

Moisture content of the sample was determined by hot air oven method (Ranganna, 1995). A test sample of $5 \mathrm{~g}$ was kept at $100^{\circ} \mathrm{C}$ in a hot air digital oven (Radical Scientific Equipment's Pvt. Ltd., 
RSTI-101) having an accuracy of $2-3^{\circ} \mathrm{C}$ for 24 hours. After 24 hour the sample was taken out and placed in a desiccator for cooling at ambient temperature.

After cooling, the weight of the dried sample was determined precisely in electronic weighing balance (Ishida UBH-620E Lab Balance) of accuracy $0.001 \mathrm{~g}$. The loss in weight was determined and moisture content was calculated using the following expression:

Moisture content $\%$ (w.b) $=$

Weight of moisture

Total Weight of Grain

\section{Size}

For the measurement of Length (a), Width (b) and Thickness (c), of Kodo grains randomly 25 grains were taken vernier caliper with least count of $0.01 \mathrm{~mm}$ was used for measurement of size of grains. Size, also called as equivalent diameter, was measured by using the method recommended by (Sahay and Singh, 2001).

$D_{g}=(a \times b \times c)^{1 / 3} \ldots \ldots \ldots \ldots \ldots . . . E q 2$

$\mathrm{D}_{\mathrm{g}}=$ size, $\mathrm{mm}$

$\mathrm{a}=$ Length, $\mathrm{mm}$

$\mathrm{b}=$ width, $\mathrm{mm}$

$\mathrm{c}=$ Thickness, $\mathrm{mm}$

\section{Sphericity}

It is the ratio of the diameter of a sphere of same volume as that of the particle and the diameter of the smallest circumscribing sphere or generally the largest diameter of the particle (Sahay and Singh, 2001).

$\mathrm{S}=(\mathrm{a} \times \mathrm{b} \times \mathrm{c})^{1 / 3} / \mathrm{a} \ldots \ldots \ldots \ldots \ldots . \mathrm{Eq} 3$

$\mathrm{a}=$ largest intercept

$\mathrm{b}=$ largest intercept perpendicular to $\mathrm{a}$

$\mathrm{c}=$ largest intercept perpendicular to $\mathrm{a}$ and $\mathrm{b}$

\section{Bulk density}

Bulk density was determined by filling a measuring cylinder of $100 \mathrm{cc}$ with grains, striking off the top level and then weighing the grains on an electronic weighing balance (Ishida UBH-620E Lab Balance) of accuracy $0.001 \mathrm{~g}$. The ratio of weight of the sample and volume occupied by it is expressed as the bulk density, g/cc (Joshi et al., 1993).

$\mathrm{B}_{\mathrm{d}}=\mathrm{W} / \mathrm{V} \ldots \ldots \ldots \ldots \ldots . \mathrm{Eq} 4$

Where,

$\mathrm{B}_{\mathrm{d}}=$ Bulk density, $\mathrm{g} / \mathrm{cc}$;

$\mathrm{W}=$ Weight of Kodo, g;

$\mathrm{V}=$ Volume of Kodo, cc.

\section{Angle of repose}

The angle of repose was measured by slump cone method (Mandhyan et al., 1987). A cylinder was filled up to top with sample and inverted on a plane (paper) surface. The paper was taken out gradually and cylinder was raised vertically, thus conical shape of the material was formed. Angle of repose was calculated by using the following expression: (Sahay and Singh, 1994).

$$
\begin{aligned}
& \emptyset=\tan ^{-1} \frac{2\left(\mathrm{H}_{\mathrm{a}}-\mathrm{H}_{\mathrm{b}}\right)}{\mathrm{D}_{\mathrm{b}}} \ldots \ldots \ldots \text { Eq } 5 \\
& \text { Where, } \\
& \emptyset=\text { Angle of repose, } \\
& \mathrm{H}_{\mathrm{a}}=\text { height of the cone, } \mathrm{cm} \\
& \mathrm{H}_{\mathrm{b}}=\text { height of the platform, cm } \\
& \mathrm{D}_{\mathrm{b}}=\text { diameter of the platform, cm }
\end{aligned}
$$

\section{Economic analysis of Kodo Millet De- husker}

Rational choice of agricultural machines is necessary as a condition of high efficiency of farm mechanization. When making decision about purchasing of machine the potential buyer takes into consideration several factors. One of most important is the price of the machine. The price determines first of all 
investment cost, but it also affects such elements of operation costs like depreciation, interest and storage. However, not always more expensive machine creates higher unitary costs. Sometimes operation costs of advanced, more reliable and productive machine are lower as compared to a less expensive, but also less reliable and less productive one. Therefore, the choice of machine should be preceded by a careful economic analysis.

\section{Results and Discussion}

\section{Engineering properties of kodo millet}

Various engineering properties viz. size, sphericity, bulk density and angle of repose of Kodo millet were determined at 12 and $14 \%$ moisture content (w.b).

\section{Size and sphericity of kodo millet}

From Table 1 and 2 it is clear that the size and sphericity of Kodo millet increased slightly with the increment in the moisture content. The average length, width, thickness, size and sphericity of Kodo millet at $12 \%$ moisture content (w.b) were $2.69 \mathrm{~mm}, 2.02 \mathrm{~mm}, 1.31$ $\mathrm{mm}, 1.92 \mathrm{~mm}$ and $71.68 \%$ respectively. However, the average values of length, width, thickness, size and sphericity of Kodo millet at $14 \%$ moisture content (w.b) were $2.80 \mathrm{~mm}$, $2.39 \mathrm{~mm}, 1.39 \mathrm{~mm}, 2.09 \mathrm{~mm}$, and $74.76 \%$ respectively. The increment in size and sphericity may be attributed to the presence of moisture inside the kernel causing slight expansion of kernels. Similar trends were observed by (Edward et al., 2002).

\section{Bulk density of kodo millet}

Table 3 represents the bulk density of Kodo millet at $12 \%$ and $14 \%$ moisture content (w.b). It was observed that the bulk density of Kodo millet decreased with increase in moisture content. The average value of bulk density of Kodo millet at 12 and $14 \%$ moisture content were 957.23 and 954.81 $\mathrm{kg} / \mathrm{m} 3$, respectively. It is an important parameter for designing of feed hopper and discharge chute of processing machineries.

\section{Angle of repose for the Kodo millet}

The results obtained are presented in Table 4. It is evident from the data that the average value of angle of repose for the Kodo millet increased from $26.23^{\circ}$ to $26.50^{\circ}$ with increment in moisture content (w.b.) from $12 \%$ and 14\%. (Balasubramanian and Vishwanathan, 2010; Shirsat et al., 2008) also observed the increment in angle of repose of Kodo millet with increment in moisture content. Angle of repose of Kodo millet was used to decide angle of inclined surfaces of trapezoidal shaped feed hopper and inclination of de-husking unit.

\section{Performance evaluation of the de-husking unit}

For performance evaluation of de-husking unit, Kodo millet was fed to the de-husking unit at $12 \mathrm{~kg} / \mathrm{hr}$ feed rate. Performance of Kodo millet de-husker, was evaluated at 340 , $360,380 \mathrm{rpm}$ with $1.5 \mathrm{~mm}$ and $2.00 \mathrm{~mm}$ clearance between the outer indented cylinder and inner rotating de-husking roller.

\section{Selection of feed rate}

Feed rate was calculated by measuring the time taken in minutes to pass the Kodo millet through feed hopper having feed slit clearance of $4 \mathrm{~mm}$ as shown in table 5 .

\section{Selection of rotational speed of de-husker}

Selection of rotational speed of de-husking roller was decided on the basis of the parameters such as rotational speed of the 
electric motor, diameters of the motor's pulley and the pulley mounted on the shaft. During trials, it was observed that the maximum de-husking of Kodo millet was at rotational speeds of de-husker 340, 360 and $380 \mathrm{rpm}$.

\section{Selection of clearance between inner de- husking roller and outer indented cylinder}

The clearance between the outer indented cylinder and the inner de-husking roller of Kodo millet de-husker was decided based on the size and sphericity of the Kodo millet.

Effect of rotational speed of de-husker, moisture content, clearance on de-husking efficiency

The de-husking efficiency of Kodo millet dehusker was dependent on speed of rotation of the inner de-husking roller, moisture content of the feed and the clearance between the outer indented cylinder and the inner dehusking roller. Coefficient of wholeness and de-husking efficiency were calculated by using the Eq. 6 and 7 respectively.

\section{Calculation of de-husking efficiency}

De-husking efficiency was calculated by following expression:

(De-husking) $\%=\{1-$ (wt. of unhusked grains /wt. of total grains

after de-husking) $\} \times \mathrm{E}_{\mathrm{wk}} \times 100$

Eq 6

Where,

Coefficient of wholeness $\left(\mathrm{E}_{\mathrm{wk}}\right)=$

\{wt. of whole kernels/ (wt. of whole kernels + wt. of brokens)\} Eq 7

Table.1 Size and Sphericity of Kodo millet at 12\% moisture content (w.b)

\begin{tabular}{|c|c|c|c|c|c|}
\hline $\begin{array}{c}\text { Number of } \\
\text { observation }\end{array}$ & Length $(\mathbf{m m})$ & Width $(\mathbf{m m})$ & $\begin{array}{c}\text { Thickness } \\
(\mathbf{m m})\end{array}$ & Size (mm) & Sphericity \% \\
\hline $\mathbf{1}$ & 2.40 & 2.21 & 1.25 & 1.87 & 77.91 \\
\hline $\mathbf{2}$ & 2.57 & 2.14 & 1.58 & 2.05 & 79.76 \\
\hline $\mathbf{3}$ & 2.65 & 1.95 & 1.16 & 1.81 & 68.30 \\
\hline $\mathbf{4}$ & 2.67 & 2.03 & 1.48 & 2.00 & 74.90 \\
\hline $\mathbf{5}$ & 2.45 & 2.28 & 1.32 & 1.95 & 79.59 \\
\hline $\mathbf{6}$ & 2.51 & 2.29 & 1.40 & 2.01 & 80.07 \\
\hline $\mathbf{7}$ & 2.45 & 1.82 & 1.22 & 1.75 & 71.42 \\
\hline $\mathbf{8}$ & 2.97 & 2.02 & 1.23 & 1.95 & 65.65 \\
\hline $\mathbf{9}$ & 2.77 & 1.97 & 1.34 & 1.94 & 70.03 \\
\hline $\mathbf{1 0}$ & 2.84 & 2.15 & 1.47 & 2.07 & 72.88 \\
\hline $\mathbf{1 1}$ & 2.80 & 1.89 & 1.38 & 1.94 & 69.28 \\
\hline $\mathbf{1 2}$ & 2.70 & 1.72 & 1.58 & 1.95 & 72.22 \\
\hline $\mathbf{1 3}$ & 2.76 & 2.06 & 1.30 & 1.95 & 70.65 \\
\hline $\mathbf{1 4}$ & 2.37 & 2.07 & 1.29 & 1.85 & 78.05 \\
\hline $\mathbf{1 5}$ & 2.77 & 2.15 & 1.28 & 1.97 & 71.11 \\
\hline $\mathbf{1 6}$ & 2.67 & 2.05 & 1.27 & 1.91 & 71.53 \\
\hline $\mathbf{1 7}$ & 2.88 & 1.67 & 1.02 & 1.69 & 58.68 \\
\hline $\mathbf{1 8}$ & 2.58 & 1.73 & 1.13 & 1.72 & 66.66 \\
\hline $\mathbf{1 9}$ & 3.00 & 1.83 & 1.30 & 1.92 & 64.00 \\
\hline $\mathbf{2 0}$ & 3.01 & 2.02 & 1.33 & 2.01 & 66.77 \\
\hline $\mathbf{2 1}$ & 2.59 & 2.38 & 1.31 & 2.00 & 77.22 \\
\hline $\mathbf{2 2}$ & 2.78 & 2.11 & 1.38 & 2.01 & 72.30 \\
\hline $\mathbf{2 3}$ & 2.59 & 1.87 & 1.26 & 1.83 & 70.65 \\
\hline $\mathbf{2 4}$ & 2.49 & 2.16 & 1.30 & 1.91 & 76.70 \\
\hline $\mathbf{2 5}$ & 2.99 & 1.98 & 1.29 & 1.97 & 65.88 \\
\hline Average & $\mathbf{2 . 6 9}$ & $\mathbf{2 . 0 2}$ & $\mathbf{1 . 3 1}$ & $\mathbf{1 . 9 2}$ & $\mathbf{7 1 . 6 8}$ \\
\hline
\end{tabular}


Table. 2 Size and sphericity of kodo millet at 14\% moisture content (w.b)

\begin{tabular}{|c|c|c|c|c|c|}
\hline $\begin{array}{l}\text { Number of } \\
\text { observation }\end{array}$ & Length (mm) & $\begin{array}{l}\text { Width } \\
(\mathrm{mm})\end{array}$ & $\begin{array}{c}\text { Thickness } \\
\text { (mm) }\end{array}$ & $\begin{array}{c}\text { Size } \\
(\mathbf{m m})\end{array}$ & $\begin{array}{c}\text { Sphericity } \\
\%\end{array}$ \\
\hline 1 & 2.74 & 2.23 & 1.45 & 2.01 & 73.35 \\
\hline 2 & 2.82 & 2.38 & 1.58 & 2.19 & 77.65 \\
\hline 3 & 2.76 & 2.28 & 1.36 & 2.04 & 73.91 \\
\hline 4 & 2.79 & 2.19 & 1.48 & 2.08 & 74.55 \\
\hline 5 & 2.94 & 2.78 & 1.52 & 2.31 & 78.57 \\
\hline 6 & 2.61 & 2.29 & 1.40 & 2.03 & 77.77 \\
\hline 7 & 2.83 & 2.42 & 1.32 & 2.08 & 73.49 \\
\hline 8 & 2.97 & 2.62 & 1.53 & 2.28 & 76.76 \\
\hline 9 & 2.77 & 2.67 & 1.34 & 2.14 & 77.25 \\
\hline 10 & 2.84 & 2.15 & 1.47 & 2.07 & 72.88 \\
\hline 11 & 2.98 & 2.29 & 1.38 & 2.11 & 70.80 \\
\hline 12 & 2.70 & 2.42 & 1.58 & 2.17 & 80.37 \\
\hline 13 & 2.76 & 2.45 & 1.36 & 2.09 & 75.72 \\
\hline 14 & 2.65 & 2.26 & 1.31 & 1.98 & 74.71 \\
\hline 15 & 2.77 & 2.35 & 1.28 & 2.02 & 72.92 \\
\hline 16 & 2.67 & 2.32 & 1.27 & 1.98 & 74.15 \\
\hline 17 & 2.88 & 2.41 & 1.23 & 2.04 & 70.83 \\
\hline 18 & 2.68 & 2.43 & 1.33 & 2.05 & 76.49 \\
\hline 19 & 3.00 & 2.63 & 1.43 & 2.24 & 74.66 \\
\hline 20 & 3.01 & 2.19 & 1.18 & 1.98 & 65.78 \\
\hline 21 & 2.59 & 2.38 & 1.31 & 2.00 & 77.22 \\
\hline 22 & 2.71 & 2.64 & 1.21 & 2.05 & 75.64 \\
\hline 23 & 2.89 & 2.37 & 1.38 & 2.11 & 73.01 \\
\hline 24 & 2.74 & 2.36 & 1.60 & 2.17 & 79.19 \\
\hline 25 & 2.99 & 2.28 & 1.45 & 2.14 & 71.57 \\
\hline Average & 2.80 & 2.39 & 1.39 & 2.09 & 74.76 \\
\hline
\end{tabular}

Table.3 Bulk density of Kodo at 12 and 14\% moisture content (w.b)

\begin{tabular}{|c|c|c|}
\hline S. No. & \multicolumn{2}{|c|}{ Bulk Density $\left(\mathrm{kg} / \mathbf{m}^{\mathbf{3}}\right)$} \\
\hline M.C. $(\mathbf{w . b .})$ & $\mathbf{1 2 \%}$ & $\mathbf{1 4 \%}$ \\
\cline { 1 - 3 } $\mathbf{1}$ & 958.77 & 955.63 \\
\hline $\mathbf{2}$ & 956.02 & 954.77 \\
\hline $\mathbf{3}$ & 956.93 & 952.79 \\
\hline $\mathbf{4}$ & 957.77 & 954.93 \\
\hline $\mathbf{5}$ & 956.69 & 955.95 \\
\hline Average & $\mathbf{9 5 7 . 2 3}$ & $\mathbf{9 5 4 . 8 1}$ \\
\hline
\end{tabular}


Table.4 Angle of repose $\left(^{\circ}\right)$ of Kodo millet

\begin{tabular}{|c|c|c|}
\hline$\frac{\text { S. No. }}{\text { M.C. (w.b.) }}$ & $12 \%$ & $14 \%$ \\
\hline 1. & 26.58 & 26.82 \\
\hline 2. & 26.63 & 26.64 \\
\hline 3. & 26.32 & 25.89 \\
\hline 4. & 25.81 & 27.45 \\
\hline 5. & 25.85 & 25.72 \\
\hline Average & 26.23 & 26.50 \\
\hline
\end{tabular}

Table.5 Selection of feed rate

\begin{tabular}{|l|c|c|c|}
\hline Feed 1 kg & $\begin{array}{c}\text { Feed Slit } \\
\text { Clearance }(\mathbf{m m})\end{array}$ & $\begin{array}{c}\text { Time taken to pass } \\
\text { through feed } \\
\text { hopper }(\mathbf{m i n})\end{array}$ & Feed rate $(\mathbf{k g} / \mathbf{h r})$ \\
\hline $\mathbf{1}$ & 4 & $4 \mathrm{~min} 58 \mathrm{sec}$ & 12.08 \\
\hline $\mathbf{1}$ & 4 & $4 \mathrm{~min} 56 \mathrm{sec}$ & 12.16 \\
\hline $\mathbf{1}$ & 4 & $4 \mathrm{~min} 60 \mathrm{sec}$ & 12.01 \\
\hline Average & & & 12.08 \\
\hline
\end{tabular}

Table.6 Effect of de-husking roller rpm on the de-husking efficiency of raw Kodo at $12 \%$ m.c, clearance $1.5 \mathrm{~mm}$ and $2 \mathrm{~m}$

\begin{tabular}{|l|c|c|c|c|c|c|c|}
\hline & & & $\begin{array}{c}\text { For } \\
\text { Clearance } \\
\mathbf{1 . 5} \mathbf{~ m m}\end{array}$ & & \\
\hline RPM & $\begin{array}{c}\text { Feed } \\
\text { Rate } \\
(\mathrm{kg} / \mathrm{hr})\end{array}$ & $\begin{array}{c}\text { Wt. of } \\
\text { Husk } \\
(\mathrm{gm})\end{array}$ & $\begin{array}{c}\text { Wt. of } \\
\text { milled } \\
\text { kodo } \\
(\mathrm{gm})\end{array}$ & $\begin{array}{c}\text { Wt. of } \\
\text { unmilled } \\
\text { kodo }(\mathrm{gm})\end{array}$ & $\begin{array}{c}\text { Wt. of } \\
\text { Broken } \\
(\mathrm{gm})\end{array}$ & $\begin{array}{c}\text { Coeff. of } \\
\text { Wholeness } \\
\left(\mathrm{E}_{\mathrm{wk}}\right)\end{array}$ & $\begin{array}{c}\text { Dehusking } \\
\text { Efficiency } \\
(\%)\end{array}$ \\
\hline $\mathbf{3 4 0}$ & 12 & 115 & 1225 & 660 & 38 & 0.968 & 66.13 \\
\hline $\mathbf{3 6 0}$ & 12 & 123 & 1257 & 620 & 42 & 0.966 & 68.01 \\
\hline $\mathbf{3 8 0}$ & 12 & 133 & 1270 & 597 & 46 & 0.963 & 69.20 \\
\hline & & & & For & & & \\
\hline $\mathbf{3 4 0}$ & 12 & 90 & 1165 & 745 & 23 & 0.980 & 61.77 \\
\hline $\mathbf{3 6 0}$ & 12 & 101 & 1185 & 714 & 25 & 0.978 & 63.22 \\
\hline $\mathbf{3 8 0}$ & 12 & 112 & 1220 & 668 & 32 & 0.973 & 65.50 \\
\hline
\end{tabular}


Table.7 Effect of de-husking roller on the de-husking efficiency of pretreated Kodo at $12 \%$ m.c (w.b), clearance $1.5 \mathrm{~mm}$ and $2 \mathrm{~mm}$

\begin{tabular}{|c|c|c|c|c|c|c|c|}
\hline & & & & $\begin{array}{c}\text { Clearance } \\
1.5 \mathrm{~mm}\end{array}$ & & & \\
\hline RPM & $\begin{array}{l}\text { Feed } \\
\text { Rate } \\
(\mathrm{kg} / \mathrm{hr})\end{array}$ & $\begin{array}{l}\text { Wt. of } \\
\text { Husk } \\
\text { (gm) }\end{array}$ & $\begin{array}{l}\text { Wt. of } \\
\text { Milled } \\
\text { kodo } \\
(\mathrm{gm})\end{array}$ & $\begin{array}{c}\text { Wt. of } \\
\text { Unmilled } \\
\text { kodo (gm) }\end{array}$ & $\begin{array}{l}\text { Wt. of } \\
\text { Broken } \\
(\mathrm{gm})\end{array}$ & $\begin{array}{c}\text { Coeff. of } \\
\text { Wholeness } \\
\left(E_{\mathrm{wk}}\right)\end{array}$ & $\begin{array}{c}\text { Dehusking } \\
\text { Efficiency } \\
(\%)\end{array}$ \\
\hline 340 & 12 & 120 & 1280 & 600 & 26 & 0.979 & 68.70 \\
\hline 360 & 12 & 135 & 1305 & 560 & 27 & 0.979 & 70.60 \\
\hline 380 & 12 & 144 & 1320 & 536 & 36 & 0.972 & 71.90 \\
\hline & & & & $\begin{array}{l}\text { Clearance } \\
2 \mathrm{~mm}\end{array}$ & & & \\
\hline 340 & 12 & 112 & 1246 & 642 & 25 & 0.979 & 66.70 \\
\hline 360 & 12 & 122 & 1258 & 620 & 28 & 0.977 & 67.74 \\
\hline 380 & 12 & 134 & 1268 & 598 & 31 & 0.975 & 68.75 \\
\hline
\end{tabular}

Table.8 Effect of de-husking roller on the de-husking efficiency of pretreated Kodo at $14 \%$ m.c., clearance $1.5 \mathrm{~mm}$ and $2 \mathrm{~mm}$

\begin{tabular}{|c|c|c|c|c|c|c|c|}
\hline & & & & $\begin{array}{c}\text { Clearance } \\
1.5 \mathrm{~mm}\end{array}$ & & & \\
\hline RPM & $\begin{array}{l}\text { Feed } \\
\text { Rate } \\
(\mathrm{kg} / \mathrm{hr})\end{array}$ & $\begin{array}{l}\text { Wt. of } \\
\text { Husk } \\
\text { (gm) }\end{array}$ & $\begin{array}{l}\text { Wt. of } \\
\text { Milled } \\
\text { kodo } \\
(\mathrm{gm})\end{array}$ & $\begin{array}{c}\text { Wt. of } \\
\text { Unmilled } \\
\text { kodo (gm) }\end{array}$ & $\begin{array}{l}\text { Wt. of } \\
\text { Broken } \\
(\mathrm{gm})\end{array}$ & $\begin{array}{c}\text { Coeff. of } \\
\text { Wholeness } \\
\left(E_{w k}\right)\end{array}$ & $\begin{array}{c}\text { Dehusking } \\
\text { Efficiency } \\
(\%)\end{array}$ \\
\hline 340 & 12 & 138 & 1310 & 552 & 40 & 0.969 & 71.27 \\
\hline 360 & 12 & 145 & 1350 & 505 & 44 & 0.967 & 73.73 \\
\hline \multirow[t]{2}{*}{380} & 12 & 168 & 1360 & 472 & 55 & 0.959 & 75.29 \\
\hline & & & & $\begin{array}{c}\text { Clearance } \\
2 \mathrm{~mm}\end{array}$ & & & \\
\hline 340 & 12 & 125 & 1293 & 582 & 32 & 0.975 & 69.70 \\
\hline 360 & 12 & 129 & 1310 & 561 & 39 & 0.97 & 71.10 \\
\hline 380 & 12 & 140 & 1330 & 530 & 48 & 0.963 & 72.51 \\
\hline
\end{tabular}


Fig.1 and 2 Isometric view of Kodo millet de-husker and developed Kodo millet de-husker

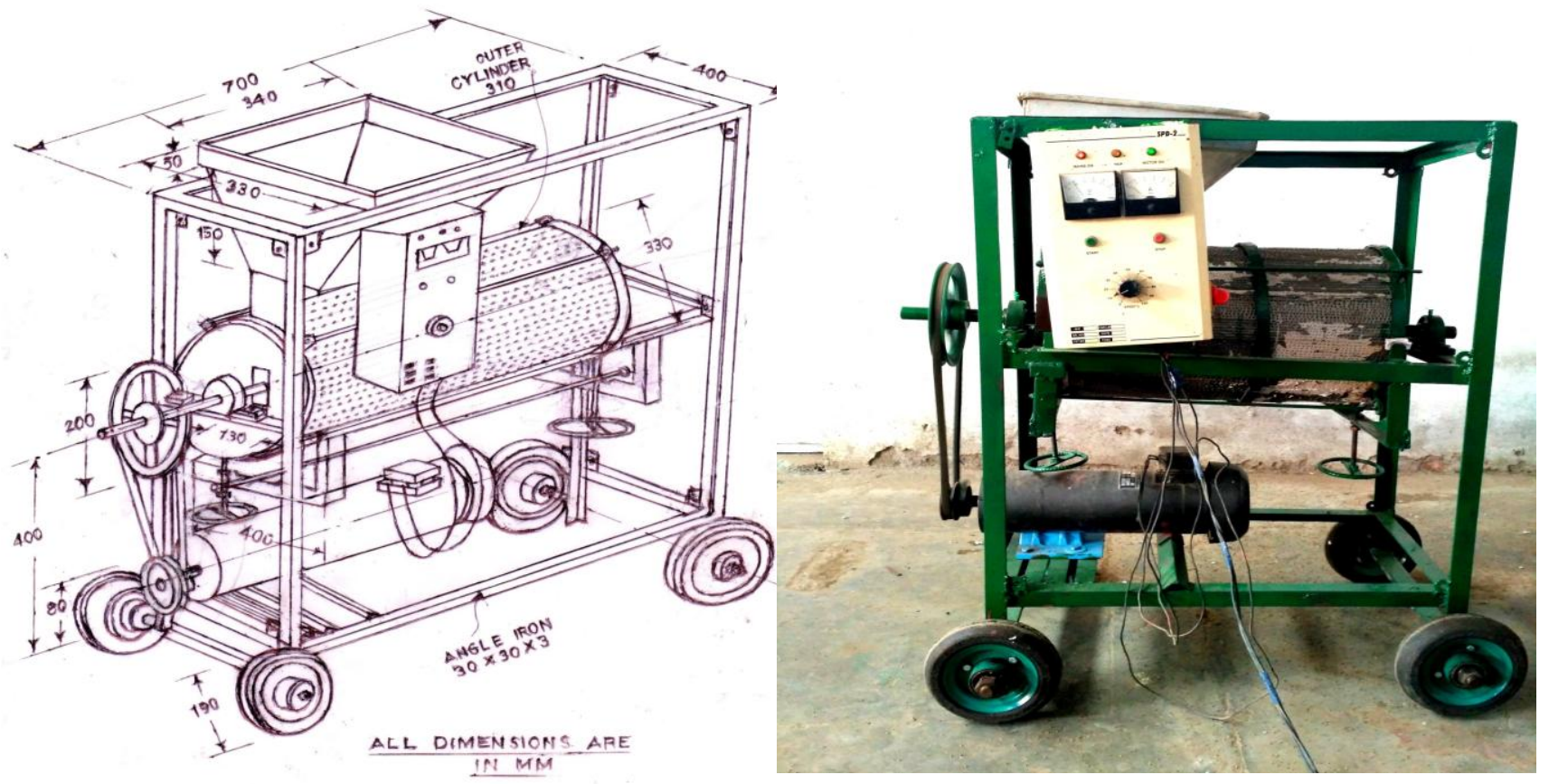

Fig.3 Forces acting on grain in de-husking unit

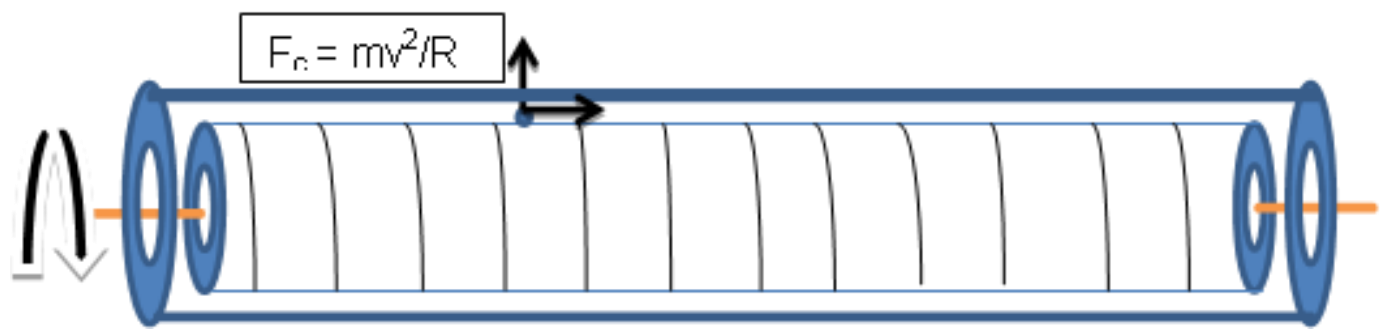

Fig.4 De-husking efficiency of raw Kodo millet at $12 \%$ m.c, at $1.5 \mathrm{~mm}$ and $2 \mathrm{~mm}$ clearance

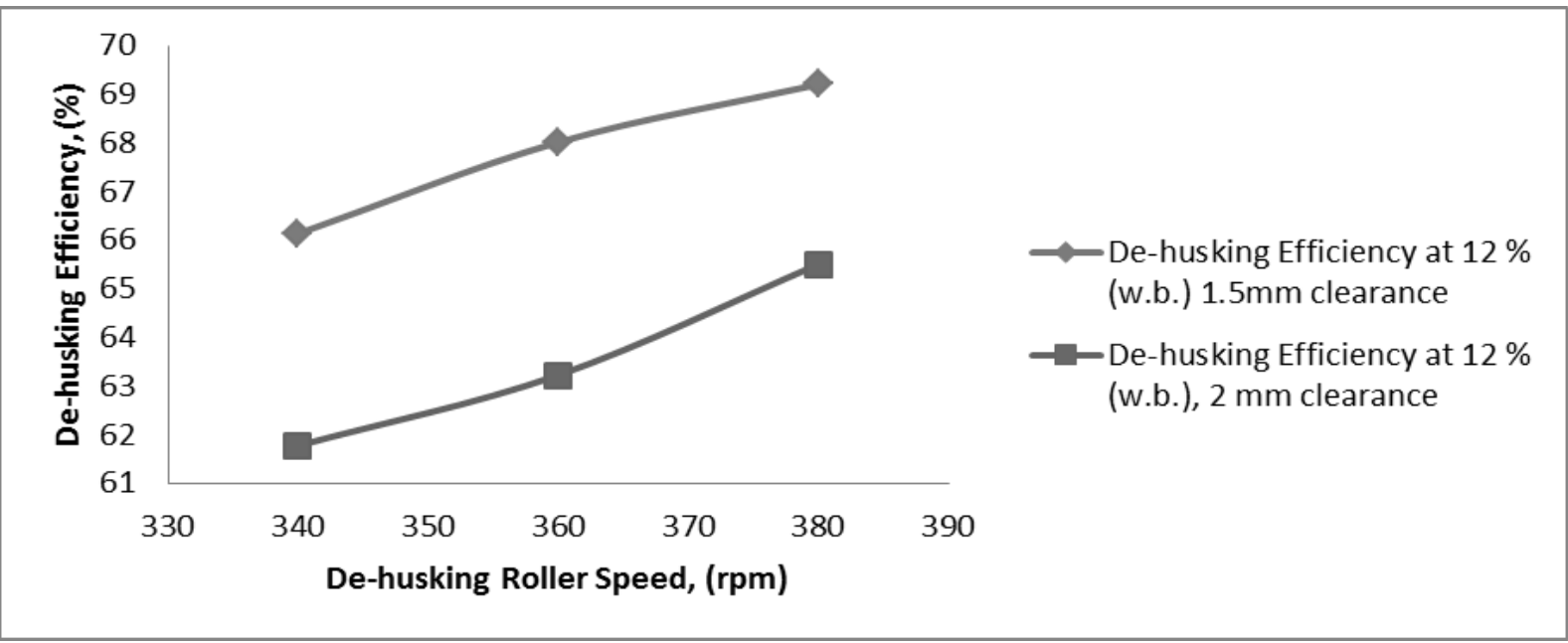


Fig.5 De-husking efficiency of pretreated Kodo at $12 \%$ m.c, $1.5 \mathrm{~mm}$ and $2 \mathrm{~mm}$ clearance

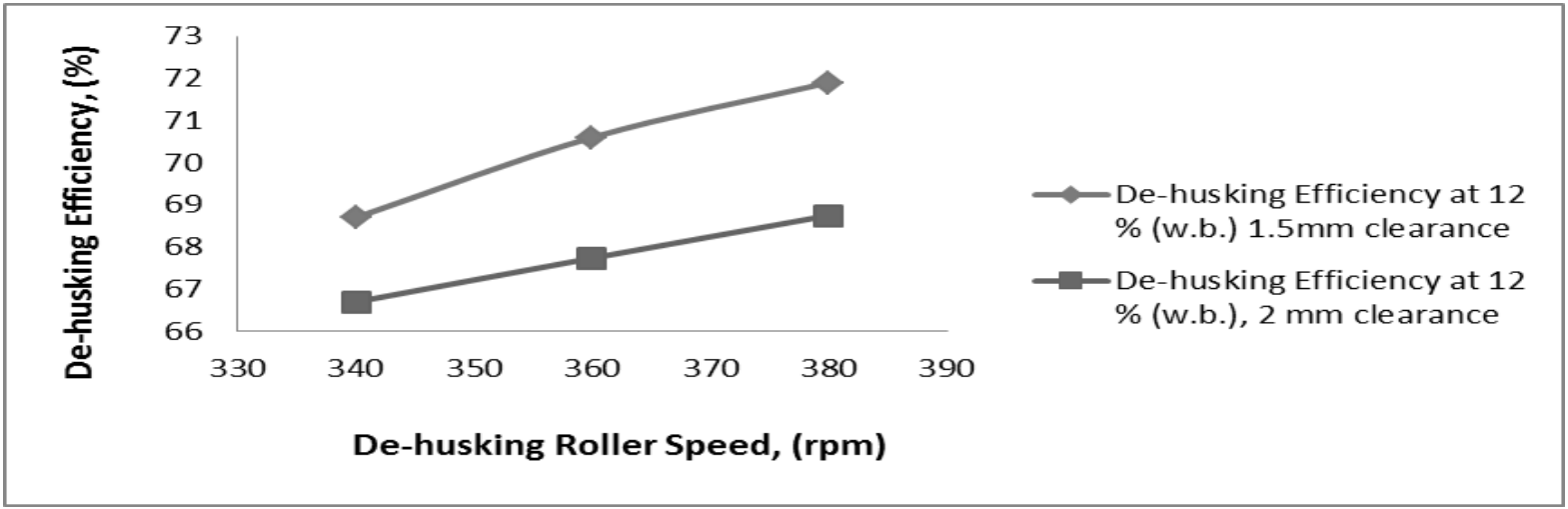

Fig.6 De-husking efficiency of pretreated Kodo at $14 \%$ m.c (w.b), with $1.50 \mathrm{~mm}$ and $2.00 \mathrm{~mm}$ clearance

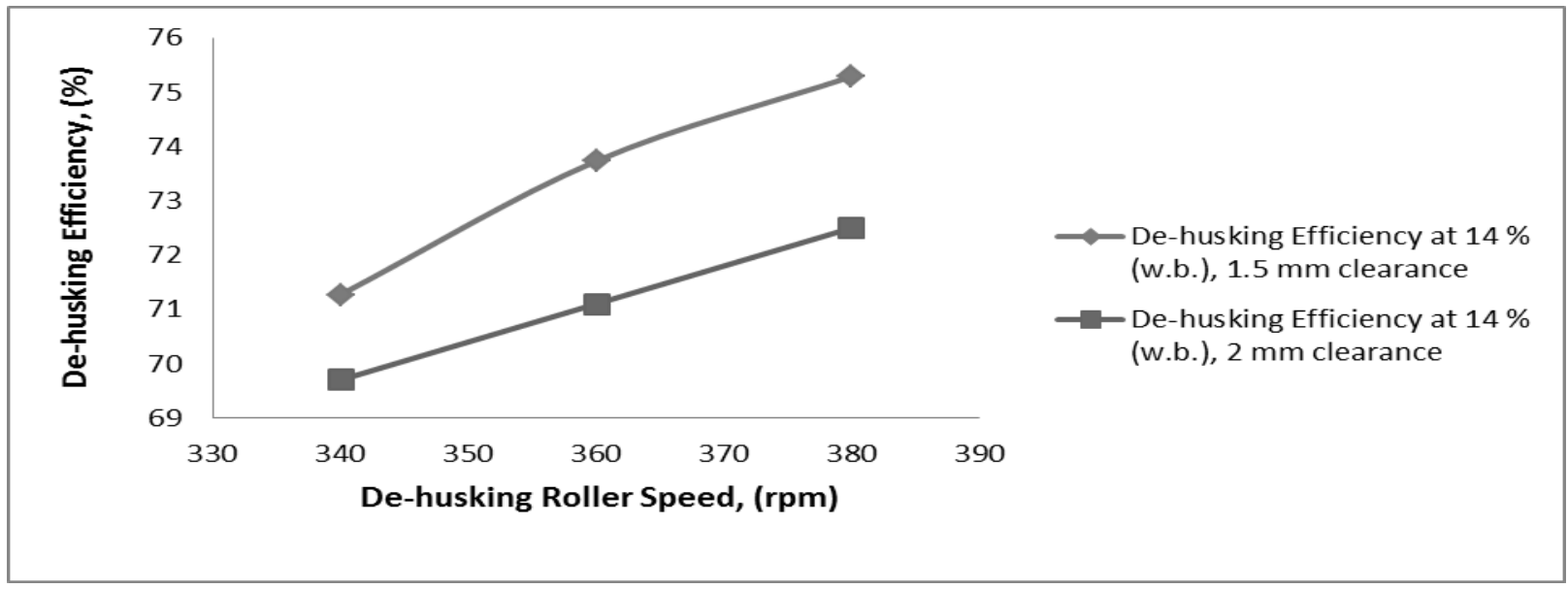

Fig.7 Various fraction of de-husked Kodo millet

(a) Husk Content at $380 \mathrm{rpm}$, (b) Milled Kodo at $380 \mathrm{rpm}$
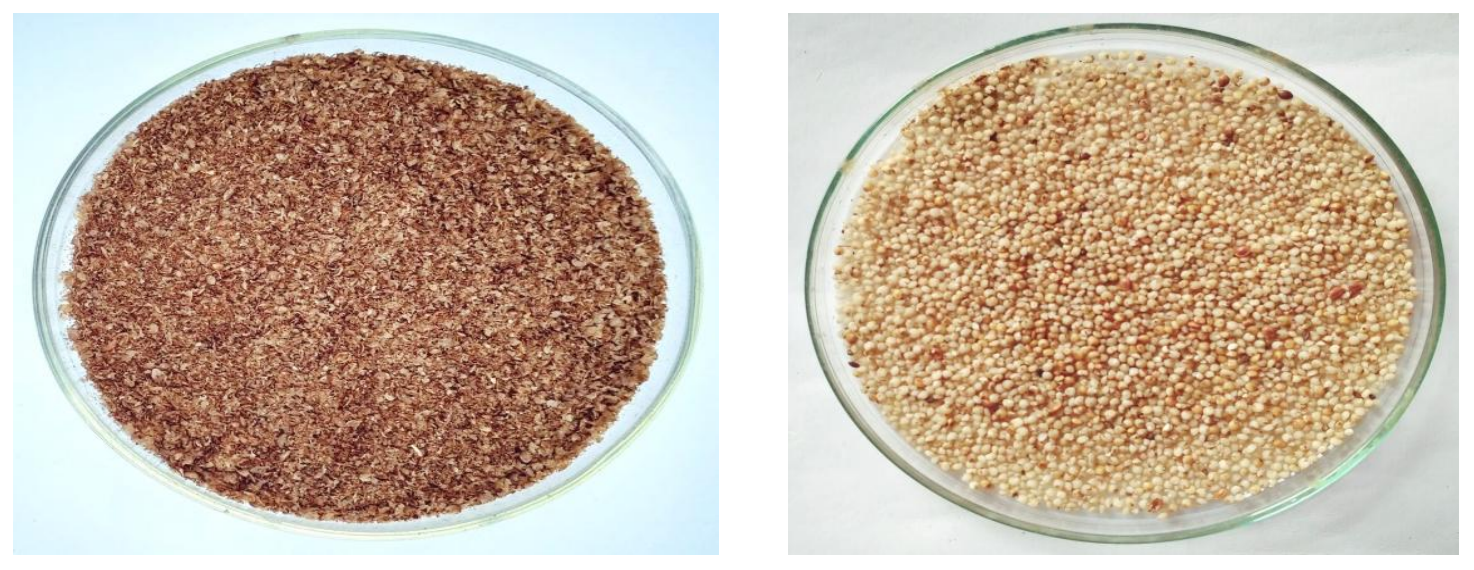


\section{De-husking efficiency of raw Kodo at $12 \%$ m.c. at $1.5 \quad \mathrm{~mm}$ and $2 \mathrm{~mm}$ clearance}

From Figure 4, it is cleared that for the same rpm of de-husking roller higher de-husking efficiency was obtained when the clearance between the outer indented cylinder and inner de-husking roller was kept smaller. At 340 rpm the de-husking efficiency was $66.13 \%$ and $61.77 \%$ when the clearance between the abrasive surfaces was $1.5 \mathrm{~mm}$ and $2 \mathrm{~mm}$ respectively. The maximum de-husking efficiency $69.2 \%$ was obtained at $380 \mathrm{rpm}$ and $1.5 \mathrm{~mm}$ clearance between the abrasive surfaces. For a particular speed of de-husking roller the weight of broken decreased marginally when the clearance between abrasive surfaces increased e.g. at $360 \mathrm{rpm}$ of de-husking roller, weight of broken were 42 gm and $25 \mathrm{gm}$ with $1.5 \mathrm{~mm}$ and $2.00 \mathrm{~mm}$ clearance, respectively (Table 6 ).

\section{De-husking efficiency of pretreated Kodo

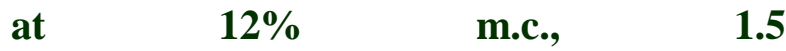
$\mathrm{mm}$ and $2 \mathrm{~mm}$ clearance

From Figure 5, it is clear that for the same speed of de-husking roller, there was an increment in de-husking efficiency, when the $1.5 \mathrm{~mm}$ clearance was maintained between the inner de-husking roller and the outer indented cylinder e.g. at $340 \mathrm{rpm}$ the dehusking efficiency was $68.70 \%$ and $66.70 \%$ when the clearance between the abrasive surfaces was $1.5 \mathrm{~mm}$ and $2 \mathrm{~mm}$, respectively.

The maximum de-husking efficiency $(71.90 \%)$ was observed at $380 \mathrm{rpm}$ in $1.5 \mathrm{~mm}$ clearance between the abrasive surfaces. The weight of broken decreased linearly when the clearance between abrasive surfaces increased at the particular rpm of de-husking roller e.g. at $360 \mathrm{rpm}$ of de-husking roller, weight of broken were $28 \mathrm{gm}$ and $27 \mathrm{gm}$ with $1.5 \mathrm{~mm}$ and $2.00 \mathrm{~mm}$ clearance, respectively (Table 7).
De-husking efficiency of pretreated Kodo at $14 \%$ m.c. (w.b), with $1.50 \mathrm{~mm}$ and 2.00 mm clearance

From Figure 4, 5 and 6 it is clear that among all trials conducted the maximum de-husking of $75.29 \%$ is obtained at $380 \mathrm{rpm}$ of inner dehusking roller at $1.5 \mathrm{~mm}$ clearance as shown in various fraction of de-husked Kodo millet (Fig. 7a) Husk Content at 380 rpm (Fig. 7a, b) Milled Kodo at $380 \mathrm{rpm}$. For same speed of de-husking roller, there was an increment in de-husking efficiency with an decrement in clearance between the abrasive surfaces, e.g. at $340 \mathrm{rpm}$ the de-husking efficiency was $71.27 \%$ and $69.70 \%$ when the clearance between the abrasive surfaces was $1.5 \mathrm{~mm}$ and $2 \mathrm{~mm}$ respectively.

For a particular speed of de-husking roller the weight of broken decreased marginally when the clearance between abrasive surfaces increased e.g. at $360 \mathrm{rpm}$ of de-husking roller, weight of broken were $44 \mathrm{gm}$ and $39 \mathrm{gm}$ with $1.5 \mathrm{~mm}$ and $2.00 \mathrm{~mm}$ clearance, respectively (Table 8).

\section{Cost analysis of kodo de-husking}

Following assumptions have been made when building the model. The maximum hours of machine work during the useful life amounts to 2000 . 10 years standard useful life has been assumed.

Therefore, the annual use of least 200 hours was necessary so that each machine could work out 2000 hours during its useful life. In case of annual use higher than 200 hours, the number of years of the useful life becomes relatively lower. Instead, in a case of a lower annual use of machines, the useful life can be prolonged up to maximum 20 years, followed by increase of the coefficient of repair costs related to the price of the machine by $30 \%$. 


\section{Input information and assumptions}

$\begin{array}{ll}\text { Cost of machine (Rs.) } & -25000.00 \\ \text { Life of machine } & -10 \text { years } \\ \text { Interest rate (per annum) } & -15 \% \\ \text { Salvage value } & -10 \% \\ \text { Operation time } & -8 \mathrm{hr} / \text { day } \\ \text { Semi-skilled labour } & -200 \mathrm{Rs} / \mathrm{day} \\ \text { Raw material } & -15 \mathrm{Rs} . / \mathrm{kg} \\ \text { Power (motor) } & -1.5 \mathrm{KW} \\ \text { Cost of housing } & -500 \mathrm{Rs} . / \mathrm{month} \\ \text { No. of labour required } & -1 \\ \text { Main product recovery } & -75 \% \\ \text { By product recovery } & -25 \% \\ \text { Market rate of millet de-husking } & -8 \mathrm{Rs} . / \mathrm{kg} \\ \text { Operation period } & -100 \mathrm{days} / \mathrm{year} \\ \text { Electricity charge } & -6.50 \mathrm{Rs} . / \mathrm{KW}-\mathrm{hr} \\ \text { Maintenance cost } & -2000 \mathrm{Rs} . / \mathrm{year}\end{array}$

Financial analysis

Working Capital Requirement (Annual) (Rs.) = Labour Charges for Working

Days (Rs./year) + Stock

(Rs./year) + Electricity

Charges (Rs/year)

$=(1 \times 25 \times 12 \times 200)+(12 \times 8 \times$

$15 \times 300)+(300 \times 6 \times 6.5)$

$=503700$

Annual Fixed Cost (Rs.) $=$ Depreciation + Interest +

Maintenance Cost + Housing

Cost + Interest on Working

Capital

$=(2500+3750+2000+6000$

$+75555)$

Annual Fixed Cost (Rs.) $=89805$

Capital investment (Rs.) $=$ Cost of equipment $+30 \%$

of working capital

Capital investment (Rs.)

Hourly variable cost (Rs.)

$=25000+151110$

$=176110$

$=503700 / 2400$

$=209.875$

Total annual cost (Rs.)

$=$ Annual fixed cost + Annual

variable cost

$=89805+503700$

$=593505$

Cost of operation (Rs.)

= Total annual cost / working 
Processing cost (Rs./kg)

$$
\begin{aligned}
& \text { hour } \\
= & 593505 / 2400 \\
= & 247.29 \\
= & (\text { Cost of operation }- \text { material } \\
& \text { cost }) / \text { capacity } \\
= & (247.29-180) / 12 \\
= & 5.60
\end{aligned}
$$

In conclusion, it is clear that among all the trials conducted the pretreated Kodo millet at $14 \%$ m.c, (w.b) with $1.50 \mathrm{~mm}$ clearance, the maximum de-husking efficiency of $75.29 \%$ was determined at $380 \mathrm{rpm}$, while at $340 \mathrm{rpm}$ and $360 \mathrm{rpm}$ the de-husking efficiency were $71.27 \%$ and $73.73 \%$ respectively. However, for pretreated Kodo millet at $14 \%$ m.c, (w.b) with $2.00 \mathrm{~mm}$ clearance, when the speed of de-husking roller increased from 340 to 380 rpm the de-husking efficiency increased from $69.70 \%$ to $72.51 \%$. De-husking efficiency of Kodo millet de-husker ranged from $72.5 \%$ to $75.29 \%$. Cost of de-husking per Kilogram of kodo millet was Rs. 5.60.

\section{References}

Afzalinia S., Shaker $M$ and Zare E. 2002.Comparision of different rice milling method. The Society For Engineering in Agricultural, Food and Biological System, 36: 21-29.

Anonymous. 2013. ICAR-CIAE Millet Mill.[ICAR News Letter, 19(2)].

Balasubramanian S., Viswanathan. 2010. Influence of moisture content on physical properties of minor millet. Journal of Food Science Technology. CIPHET Ludhiana, 47(3): 279-284.

Dixit AK., Nanda SK., Singh KP., Kudos
SKA. 2011. Economic benefits of Vivek millet thresher cum-pearler and agro processing centre in hilly region of Uttarakhand, Journal of Hill Agriculture 2(2): 177-182.

Edward A, Barhey. 2002. Physical properties of millet. Journal of food engineering 51(2002):

39-46. http//www.dhan.org/smallmillets/docs/r eport/TNAU-Model-Millet Dehuller.pdf

Joshi DC., Das SK., Mukherjee RK.1993. Physical properties of pumpkin seeds. Journal of Agricultural Engineering Research, 54(3): 219-229.

Ranganna S. 1995. Manual for the Analysis of Fruits and Vegetables. Tata MeGrawHill Publishing Co. New Delhi.

Sahay KM., Singh KK. 1994. Unit operation of agricultural processing. New Delhi, Vikas Publishing House Pvt. Ltd.

Sahay KM., Singh KK. 2001. Unit operation of agricultural processing. Second Revised Edition, New Delhi: Vikas Publishing House Pvt. Ltd. pp. 46-47, pp. 261-263.

Sirsat B., Patel S. 2008. Studies on hydration and milling characteristics of Kodo millet. International Journal of Agricultural Science. 4(2): 712-718.

\section{How to cite this article:}

Parv Nayak, A.K. Gupta, Preeti Jain and Sheela Pandey. 2019. Effect of Moisture and Machine Parameters on De-husking Efficiency of Kodo Millet. Int.J.Curr.Microbiol.App.Sci. 8(02): 1792-1804. doi: https://doi.org/10.20546/ijcmas.2019.802.211 